\title{
HAPPINESS AND HEALTHCARE THROUGH BUDDHISM
}

In Happiness And Contemporary Society : Conference Proceedings Volume (Lviv, March, 20-21, 2021). Lviv: SPOLOM, 2021. P. 86. https://doi.org/10.31108/7.2021.17

ISBN 978-966-919-697-2 


\section{DISSANAYAKE Ishini Samadhi}

Student, Department of History, University of Peradeniya, (Peradeniya, Sri Lanka)

\section{HAPPINESS AND HEALTHCARE THROUGH BUDDHISM}

Health is one of the most significant incomes of happiness and well-being. Since ancient times, Buddhism has been intimately intertwined with the avoidance of human suffering. Two thousand five hundred years ago, the supreme Buddha preached about the importance of keeping the mind happy and health care. The Buddha, preached as a doctor, talked about how stress affects our mental health and wellbeing, and that the cure for ailments related to mental health is to understand the Dhamma, and that valuable Dhamma is illustrated in the Suttas. The main objective of this research is to study about the content of Buddhism and its importance on how to get health care through happiness. The secondary objective is to study whether it is possible to achieve a healthy life through happiness with the help and the incorporation of Buddhist sermons. The research uses primary and secondary data. Primary data are collected through participant observation and interviews. Secondary data are obtained from both published and unpublished sources. As further data gathered, embracing the teachings of the Buddha into our lives brings peace of mind and it will lead us to the progressive path of being healthy. The best example of this is the supreme Buddha. Since, he has been the first to heal all the sufferings and to demonstrate to the world the worth and importance of it and how to achieve a healthy and balanced life through it.

Key Words: Happiness, Healthcare, Buddhism, Mind, Peace. 